\title{
Headache and comorbidity in pediatric age
}

\author{
Alberto Verrotti, Ilaria Bizzarri, Giulia Cecconi, Lorenza Di Genova, Manuela Vultaggio, Marta Cofini \\ From 70th Congress of the Italian Society of Pediatrics, Joint National Meeting SIP, SICUPP, SITIP \\ Palermo, Italy. 11-14 June 2014
}

\section{Background}

Frequently headache is associated with numerous comorbidities, but data are incomplete and sometimes conflicting.

The aim of this review is to highlight the relation between headache and associated disorders.

\section{Materials and methods}

We identified studies via PubMed search indexed for MEDLINE using "headache comorbidity and children" as key words. The time period covered was approximately 10 years. Only English language articles were reviewed.

\section{Results}

The findings of our research demonstrate that epilepsy, anxiety/depression, attention deficit/hyperactivity disorder (ADHD), obesity and childhood abuse are the most frequent and investigated headache-comorbidities.

Headache and epilepsy is the most frequent comorbidity in pediatric age [1-3]. The major association is with focal epilepsies, in particular criptogenetic ones $[4,5]$. The real effect of headache on seizure-related-headache is still unclear. Peri-ictal headache is a common feature of epileptic seizures: it can occur before, during or after seizures [6]. Although family history of headache and/or epilepsy is referred, there is not a clear association with specific type of both disorders [5].

Moreover, migraineurs have a higher prevalence of anxiety/depression than controls $[7,8]$. Severity of anxiety/ depression is linked with severity and frequency of migraine [9]. Therefore, parents and relatives of migraneurs are affected by both headache and psychiatric disorders [10].

Another important comorbidity is headache and ADHD [11]. Headache is not associated with ADHD overall but with iperactivity/impulsivity symptoms [12]. While the relation with inactivity symptoms is controversial, differences between headache types and ADHD have

Department of Pediatrics, University of Perugia, Perugia, 06132, Italy been not found [13]. Structural and functional abnormalities in the brain networks seem to be central in both headache and ADHD pathophysiology [14].

It has been demonstrated an association between migraine and obesity, but the real link is still matter of debate. Psychological conditions and inflammatory mediators may be involved, as a common pathophysiologic mechanism [15]. Body mass index seems to be related to high frequency, degree of migraine attacks [16-18], and chronic migraine [19].

Many studies evidence the relationship between migraine and childhood abuse. The emotional abuses' prevalence in migraineurs is higher than controls and it is more common in women [20]. Childhood maltreatment appears to be related to chronic and disabling headache [21]. This pattern leads to an early life stress that influences the neurobiological physiology [22].

\section{Conclusions}

Further studies are needed to obtain detailed epidemiological data and to understand whether common mechanism(s) below these conditions exists. Physicians should consider and investigate the possible co-occurrence of these disorders in patients with headache.

\section{Published: 11 August 2014}

\section{References}

1. Bellini B, Arruda M, Cescut A, Saulle C, Persico A, Carotenuto M, Gatta M, Nacinovich R, Piazza FP, Termine C, Tozzi E, Lucchese F, Guidetti V: Headache and comorbidity in children and adolescents. J Headache Pain 2013, 14:79.

2. Lateef TM, Cui L, Nelson KB, Nakamura EF, Merikangas KR: Physical comorbidity of migraine and other headaches in US adolescents. J Pediatr 2012, 161:308-313.

3. Kelley SA, Hartman AL, Kossoff EH: Comorbidity of migraine in children presenting with epilepsy to a tertiary care center. Neurology 2012, 79:468-473.

4. Wirrell EC, Hamiwka LD: Do children with benign rolandic epilepsy have a higher prevalence of migraine than those with other partial epilepsies or nonepilepsy controls? Epilepsia 2006, 47:1674-1681.

5. Toldo I, Perissinotto E, Menegazzo F, Boniver C, Sartori S, Salviati L, Clementi M, Montagna P, Battistella PA: Comorbidity between headache 
and epilepsy in a pediatric headache center. J Headache Pain 2010, 11:235-240.

6. Verrotti A, Coppola G, Spalice A, Di Fonzo A, Bruschi R, Tozzi E, lannetti P, Villa MP, Parisi P: Peri-ictal and inter-ictal headache in children and adolescents with idiopathic epilepsy: a multicenter cross-sectional study. Childs Nerv Syst 2011, 27:1419-1423.

7. Pakalnis A, Butz C, Splaingard D, Kring D, Fong J: Emotional problems and prevalence of medication overuse in pediatric chronic daily headache. J Child Neurol 2007, 22:1356-1359.

8. Pavone P, Rizzo R, Conti I, Verrotti A, Mistretta A, Falsaperla R, Pratico AD, Grosso G, Pavone L: Primary headaches in children: clinical findings on the association with other conditions. Int I Immunopathol Pharmacol 2012, 25:1083-1091.

9. Ligthart L, Gerrits MM, Boomsma DI, Penninx BW: Anxiety and depression are associated with migraine and pain in general: an investigation of the interrelationships. J Pain 2013, 14:363-370.

10. Galli F, Canzano L, Scalisi TG, Guidetti V: Psychiatric disorders and headache familial recurrence: a study on 200 children and their parents. $J$ Headache Pain 2009, 10:187-197.

11. Genizi J, Gordon S, Kerem NC, Srugo I, Shahar E, Raivid S: Primary headaches, attention deficit disorder and learning disabilities in children and adolescents. J Headache Pain 2013, 14:54.

12. Arruda M, Guidetti V, Galli F, Albuquerque RC, Biqual ME: Migraine, tension-type headache, and attention-deficit/hyperactivity disorder in childhood: a population-based study. Postgrad Med 2010, 122:18-26.

13. Riva D, Usilla A, Aggio F, Vago C, Treccani C, Bulgheroni S: Attention in children and adolescents with headache. Headache 2012, 52:374-384.

14. Parisi P, Verrotti A, Paolino MC, Ferretti A, Raucci U, Moavero R, Villa MP, Curatolo P: Headache and attention deficit and hyperactivity disorder in children: Common condition with complex relation and disabling consequences. Epilepsy Behav 2014, 32:72-75.

15. Verrotti A, Di Fonzo A, Agostinelli S, Coppola G, Margiotta M, Parisi P: Obese children suffer more often from migraine. Acta Paediatr 2012 101:416-421.

16. Hershey AD, Powers SW, Nelson TD, Kabbouche MA, Winner P, Yonker M, Linder SL, Bicknese A, Sowel MK, McClintock W, American Headache Society Pediatric Adolescent Section: Obesity in the pediatric headache population: A multicenter study. Headache 2009, 49:170-177.

17. Kinik ST, Alehan F, Erol I, Kanra AR: Obesity and paediatric migraine. Cephalalgia 2010, 30:105-109.

18. Pakalnis A, Kring D: Chronic Daily Headache, Medication Overuse, and Obesity in Children and Adolescents. J Child Neurol 2012, 27:577-580.

19. Bigal ME, Lipton RB: Obesity is a risk factor for transformed migraine but not for chronic tension-type headache. Neurology 2006, 67:252-257.

20. Tietjen GE, Brandes JL, Peterlin BL, Eloff A, Dafer RM, Stein MR, Drexler E, Martin VT, Hutchinson S, Aurora SK, Recober A, Herial NA, Utley C, White L, Khuder SA: Childhood maltreatment and migraine (part I). Prevalence and adult revictimization: a multicenter headache clinic survey. Headache 2010, 50:20-31.

21. Tietjen GE, Brandes JL, Peterlin BL, Eloff A, Dafer RM, Stein MR, Drexler E, Martin VT, Hutchinson S, Aurora SK, Recober A, Herial NA, Utley C, White L, Khuder SA: Childhood maltreatment and migraine (part II). Emotional abuse as a risk factor for headache chronification. Headache 2010 50:32-41.

22. Walsh CA, Jamieson E, Macmillan H, Boyle M: Child abuse and chronic pain in a community survey of women. J Interpers Violence 2007, 22:1536-1554.

doi:10.1186/1824-7288-40-S1-A83

Cite this article as: Verrotti et al:: Headache and comorbidity in pediatric age. Italian Journal of Pediatrics 2014 40(Suppl 1):A83.

\section{Submit your next manuscript to BioMed Central and take full advantage of:}

- Convenient online submission

- Thorough peer review

- No space constraints or color figure charges

- Immediate publication on acceptance

- Inclusion in PubMed, CAS, Scopus and Google Scholar

- Research which is freely available for redistribution

Submit your manuscript at www.biomedcentral.com/submit
Biomed Central 